\title{
Settlement Analysis of Recycled Concrete Fine Aggregate Blended Soils using Geostudio
}

\author{
J. Y. V. Shiva Bhushan, Raj Kumar
}

\begin{abstract}
Crushed concrete (CC) is one of the most abundant waste materials generated from construction industry. This material is widely recycled and used in various applications like pavement, concrete aggregates and backfilling. Crushed concrete is mixed with any of virgin soil to increase the engineering properties of soil. In the present study, a sample of crushed concrete is collected from demolished buildings at Secunderabad and the material is segregated according to gradation for the present study. The index properties of crushed concrete like $\mathrm{pH}$, specific gravity, water absorption, particle size distribution are obtained. Locally available soil is partially replaced i.e., 30\%, $50 \%$, and $70 \%$ with crushed concrete fine aggregates and its compaction characteristics and shear strength parameters are determined. In the continuation of the study, a numerical model is developed using a finite element software i.e GeoStudio Sigma/w. Mesh and boundary extent convergence studies are done for the model. The top $1 \mathrm{~m}$ virgin soil is replaced with the mixture of $\mathrm{CC}$ and soils. Settlements for various percentages of CC and for different width of footing are obtained for a uniform stress of $200 \mathrm{kPa}$. The stress is applied in 5 stages in order to simulate real field conditions. It was observed that $30 \%$ replacement of CC have given the least settlement for all widths of footing considered in the study
\end{abstract}

Keywords : Crushed concrete; foundation; settlements

\section{INTRODUCTION}

With the rapid increase in population and infrastructure in and around major cities of India, the need for construction materials had increased very high in recent past. Central government had implemented Smart cities Mission in 2014 and for these several projects like metro rails, ring roads, flyovers, high rise buildings etc., the demand for building materials for concrete production, pavements, and backfilling purposes had increased drastically. Exploitation of natural resources for aggregates is high with increase in demand.

For meeting the rising demand, the need for recycling the waste is necessary. The objective of the current study is to examine the applicability of recycled aggregate waste as a foundation material. Every year millions of tons of Construction and Demolition Waste (C\&D) waste are

Revised Manuscript Received on December 30, 2019.

* Correspondence Author

J Y V Shiva Bhushan*, Department of Civil Engineering, VNR VJIET, Hyderabad, India. Email: jyvshivabhushan@gmail.com

V. Raj Kumar, Department of Civil Engineering, VNR VJIET, Hyderabad, India. Email: raj20raja20@gmail.com

(C) The Authors. Published by Blue Eyes Intelligence Engineering and Sciences Publication (BEIESP). This is an open access article under the CC BY-NC-ND license (http://creativecommons.org/licenses/by-nc-nd/4.0/) generated due to rapid urbanization and natural calamities like Chennai floods 2015 etc. This C\&D waste includes waste from demolished structures due to renovations of existing structures and repair of roads, flyovers, bridges, etc. Construction and demolition (C\&D) waste constitute a major proportion of waste materials present in landfills worldwide. Recycled concrete (RC) contributes more of C\&D waste with the rapid urbanization and infrastructure development. With the shortage of high-quality quarry aggregates, alternative materials, such as CC/Recycled cement aggregates (RCA) are increasingly being considered as a replacement for various civil engineering applications. RC material has numerous environmental benefits with more sustainability. In this research, the index properties of crushed concrete like $\mathrm{pH}$, water absorption, specific gravity, particle size distribution are obtained. Crushed concrete fine aggregate was replaced partially in the percentages of $0,30,50,70$ and 100 with the locally available soil.

In the continuation of this study, crushed concrete fine aggregate was replaced with locally available soil in the percentages of 30, 50, and 70 and analyzed in GeoStudio Sigma/w software.

This sigma/w software is a finite element software helps to analyze the stress and deformations at various depths for the given pressure. A finite element model was created in the software. The top $1 \mathrm{~m}$ layer of soil was replaced with mixture of RC-FA and soil layer.

\section{MATERIALS}

Material passing through $4.75 \mathrm{~mm}$ and retained on $75 \mu$ were taken for experiment were taken from both crushed concrete and red soil. RC was obtained from demolished building near Secunderabad, which was approximately 20-year-old. Figure 1 shows the demolished material. This material was processed with the help of a crusher (Fig 2) in Osmania University. The material was graded in the ranges of $40 \mathrm{~mm}, 25 \mathrm{~mm}$, and $10 \mathrm{~mm}$ sizes and were separately collected. The material is further crushed to make sure that material is not susceptible to particle breakage.

This composition was oven dried and mixed the sample as per literature available for crushed concrete. The maximum particle had been limited to $4.75 \mathrm{~mm}$. The gradation of the mixture was considered from the literature to match with the requirements of well-graded sand, so that it can be used for various geotechnical applications. The soil used was a conventional red soil which is available from Bachupally area, Hyderabad.

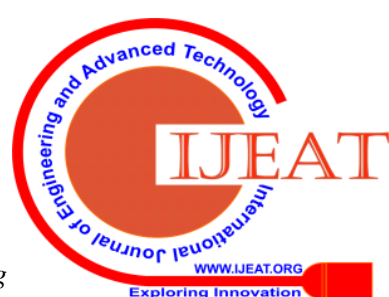




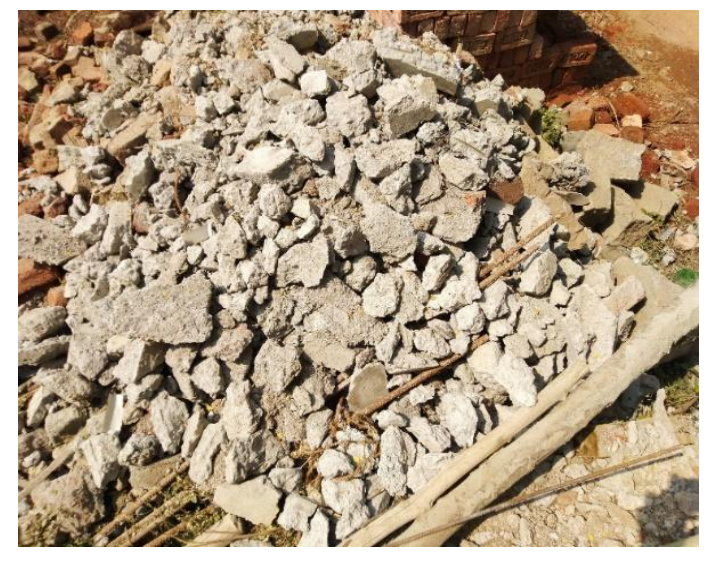

Fig. 1. Material obtained from demolished building

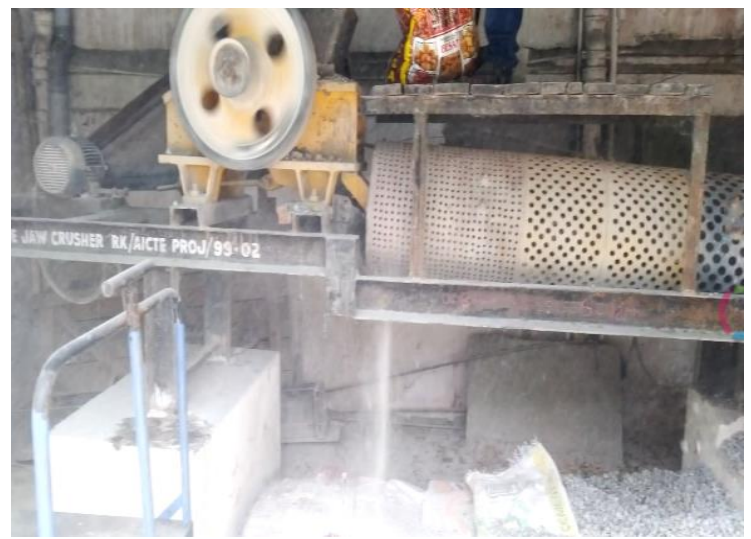

Fig. 2. Equipment used for crushing the concrete

\section{METHODOLOGY}

PH test of Red soil and CC was determined as per IS-2720Part 26, to know the nature of soil when water is added. Specific gravity and water absorption of Red soil and CC was determined as per IS-2720-Part 3. Particle size distribution of soil was determined as per IS-2720- Part-4. Compaction parameters of soil was performed with percentages mixture of CCFA according to IS-2720: Part 8. Direct shear test was performed to know the cohesion and shear parameters of the Soil as per IS-2720- Part 13. The parameters obtained from the Direct shear test are defined in the Sigma/w Software to find the stress and deformations when the soil is replaced top $1 \mathrm{~m}$ with percentage mixture of CC and Soil.

The geotechnical characterization of $C \& D$ waste was performed by Bhushan et al. (2019) [8] and it was observed that the materials from different sources can alter the engineering properties. Crushed concrete exhibit a wide range of friction angles and apparent cohesion. When 100\% RCA added with 3\% general blend cement (Arulrajah et al. 2015[5]) using maximum size as $20 \mathrm{~mm}$ based on Australian Standard Compaction parameters are OMC $=11.7 \%, \mathrm{MDD}=$ $20 \mathrm{kN} / \mathrm{m}^{3}$. Compaction test and direct shear test for various proportions i.e., $100 \%$ CC, 70\% CC and 30\% Red soil, 50\% CC and 50\% Red soil, 30\% CC and 70\% Red soil was performed to find shear parameters of the Red soil mixtures.

\section{RESULTS AND DISCUSSIONS}

Specific gravity of RC-FA is higher than red soil since it is granular material. Gradation of red soil and RC-FA was taken as $\mathrm{SW}$. pH of RC-FA was alkaline in nature due to presence of lime $(\mathrm{CaO})$ in recycled concrete. The values of gradation parameters, specific gravity and $\mathrm{pH}$ are shown in Table- I

Table- I: Index geotechnical properties of materials

\begin{tabular}{|c|c|c|}
\hline \multirow{2}{*}{ Geotechnical properties } & \multicolumn{2}{|c|}{ Values obtained for } \\
\cline { 2 - 3 } & Red soil & RC-FA \\
\hline $\mathrm{D}_{10}(\mathrm{~mm})$ & 0.2 & 0.23 \\
$\mathrm{D}_{30}(\mathrm{~mm})$ & 0.8 & 1.3 \\
$\mathrm{D}_{60}(\mathrm{~mm})$ & 1.85 & 2.5 \\
\hline $\mathrm{C}_{\mathrm{c}}$ & 9.25 & 10.86 \\
\hline $\mathrm{C}_{\mathrm{u}}$ & 1.72 & 2.9 \\
\hline IS classification & $\mathrm{SW}$ & $\mathrm{SW}$ \\
\hline $\mathrm{G}$ & 2.66 & 2.76 \\
\hline $\mathrm{pH}$ & 7.37 & 11.39 \\
\hline
\end{tabular}

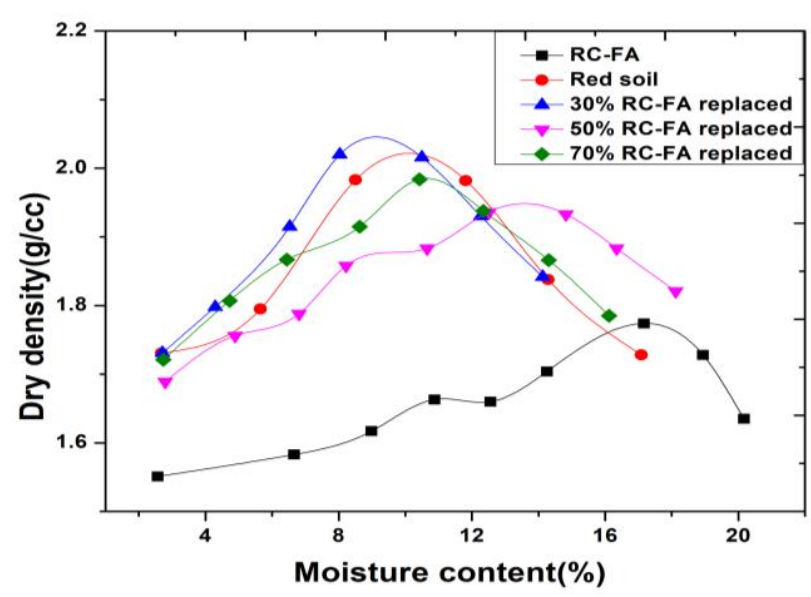

Fig. 3. Compaction characteristics of material

The modified compaction characteristics of various combinations of RC-FA and red soil are shown in Fig 3. It is observed that RC-FA needs more water content to reach its maximum dry density whereas red soil being SW needs less water content comparatively. As $30 \%$ of red soil was replaced by RC-FA, optimum moisture content had increased and maximum dry density had decreased slightly respectively. Further increase in the percentage of replacement it behaves more like RC-FA than the red soil.

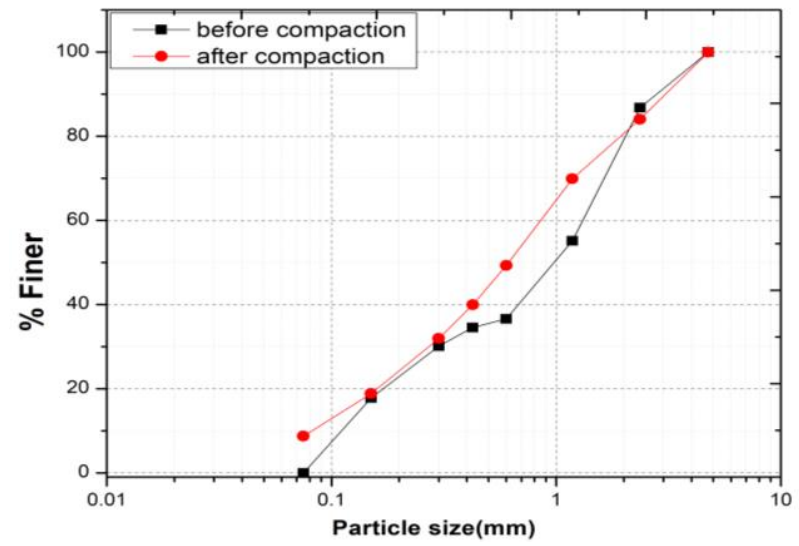

Fig. 4. Particle size distribution of RC-FA before and after compaction

Published By:

Blue Eyes Intelligence Engineering \& Sciences Publication 
To assess the crushability of CC, grain-size analysis post compaction analysis was performed done by comparing the two gradations that is before and after compaction shown in Fig 4. It is observed that particle size in between $0.3-$ $1.18 \mathrm{~mm}$ were increased.

Table-II: Shear strength parameters of blended soils

\begin{tabular}{|c|c|c|}
\hline $\begin{array}{c}\text { \% RC-FA } \\
\text { added }\end{array}$ & Cohesion(kPa) & $\begin{array}{c}\text { Angle of } \\
\text { shearing } \\
\text { resistance( } \mathbf{\Phi})\end{array}$ \\
\hline 0 & 0 & 42.2 \\
\hline 30 & 10.45 & 40.26 \\
\hline 50 & 1 & 44.27 \\
\hline 70 & 10.15 & 29.81 \\
\hline 100 & 7.3 & 36.5 \\
\hline
\end{tabular}

The values of shear strength parameters are shown in Table-II and it was observed the cohesion reaches high at $30 \%$ and angle of shearing resistance is high at $50 \%$ replacement of RC-FA as . The shear strength profiles of materials (as shown in Fig 5,) clearly indicate that with the increase in percentage of RC-FA, the shear strength increases upto $30 \%$ and then decreases.

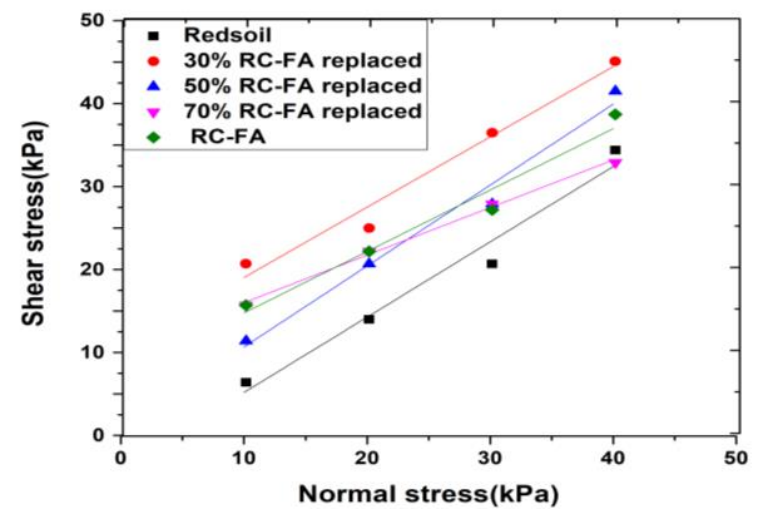

Fig. 5. Shear strength properties of material

The material is to be used as foundation material as a part of ground improvement technique replacing the top 1meter of existing weak soil with RC-FA and soil mixture. In the present study, a model was created in Sigma module of Geostudio as shown in Fig 6. Axisymmetric condition was generated. Loading had been given with time at a time interval of 30days till a pressure of $200 \mathrm{kPa}$ is transferred on to the footing. The incremental stress corresponding settlements at base of footing are shown in Fig 7.

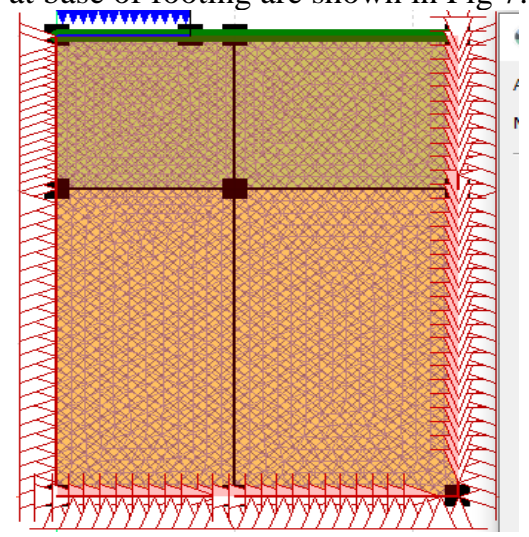

Fig. 6. Footing model after assigning materials, boundary conditions and mesh element size

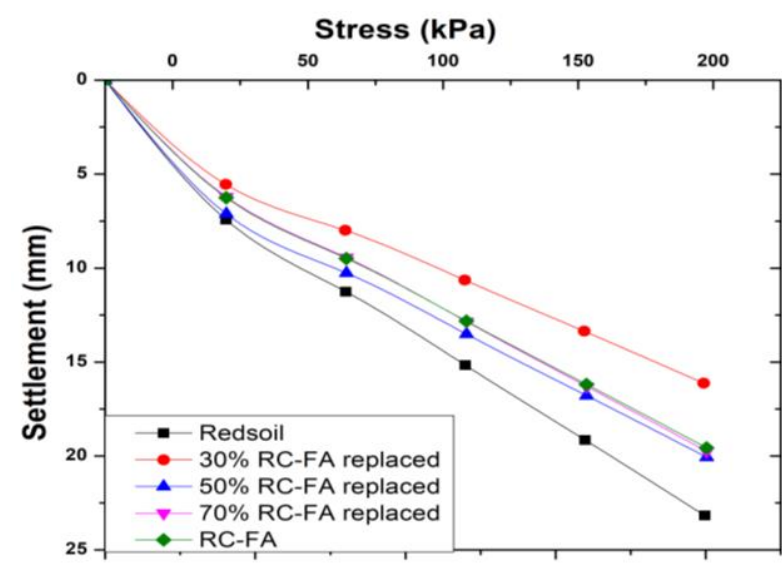

Fig. 7. Incremental Stress settlement curves

The validation of the results was done using the analytical formula for elastic settlements. The elastic settlements from Poulos and Davis were compared with the present model. The mesh and boundary convergence were checked by taking the various mesh sizes and boundary sizes. Figure 8 shows the stress contours under the footing when a stress of $200 \mathrm{kPa}$ was applied. Various footing sizes (i.e. $0.3 \mathrm{~m}, 0.6 \mathrm{~m}, 0.9 \mathrm{~m}$, $1.2 \mathrm{~m}, 1.5 \mathrm{~m}$ ) were considered to study the settlements in each case.

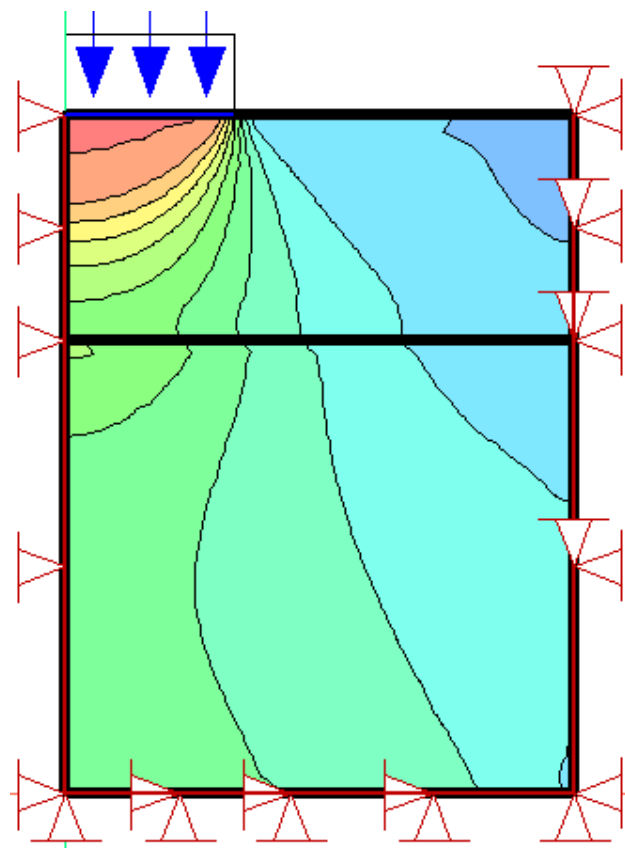

Fig. 8. Stress Contours under the footing

Settlement at base of footing at final stage of loading are mentioned in Table-III. It was observed that 30\% replacement of RC-FA had given the least settlements irrespective of size of footing. The settlement within the replaced portion of foundation soil i.e., top $1 \mathrm{~m}$ depth below footing is analysed Settlements along the depth of the soil was plotted in Fig 9.

Published By:

Blue Eyes Intelligence Engineering \& Sciences Publication 
The settlement ratio (settlement / width of footing $(S / B)$ ) versus normalised width of footing (width/ depth of soil replaced $(B / Z))$ is shown in Fig 10 to generalize for various dimensions of width of footing and depth of replacement.

Table-III: Maximum settlements with respect to change in size of footings.

\begin{tabular}{|c|c|c|c|c|c|}
\hline \multirow{2}{*}{$\begin{array}{c}\text { Size of } \\
\text { Footing }\end{array}$} & \multicolumn{5}{|c|}{ MAXIMUM SETTLEMENT (mm) @ 200 kPa } \\
\hline & $\begin{array}{l}\text { RED } \\
\text { SOIL }\end{array}$ & $\begin{array}{l}30 \% \\
\text { RC-FA }\end{array}$ & $\begin{array}{l}50 \% \\
\text { RC-FA }\end{array}$ & $\begin{array}{l}70 \% \\
\text { RC-FA }\end{array}$ & RC-FA \\
\hline 0.3 & 8.4 & 6.2 & 6.5 & 6.1 & 6.0 \\
\hline 0.6 & 13.1 & 9.4 & 10.3 & 9.7 & 9.6 \\
\hline 0.9 & 17.2 & 12.8 & 13.8 & 13.3 & 13.1 \\
\hline 1.2 & 20.4 & 16.1 & 17.1 & 16.6 & 16.5 \\
\hline 1.5 & 23.1 & 19.1 & 20.0 & 19.7 & 19.5 \\
\hline
\end{tabular}

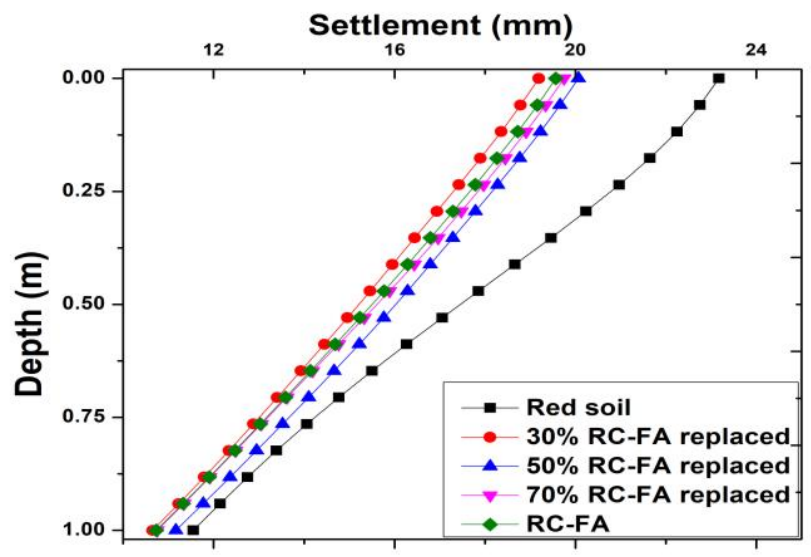

Fig. 9. Variation of settlement within top $1 \mathrm{~m}$ replaced depth

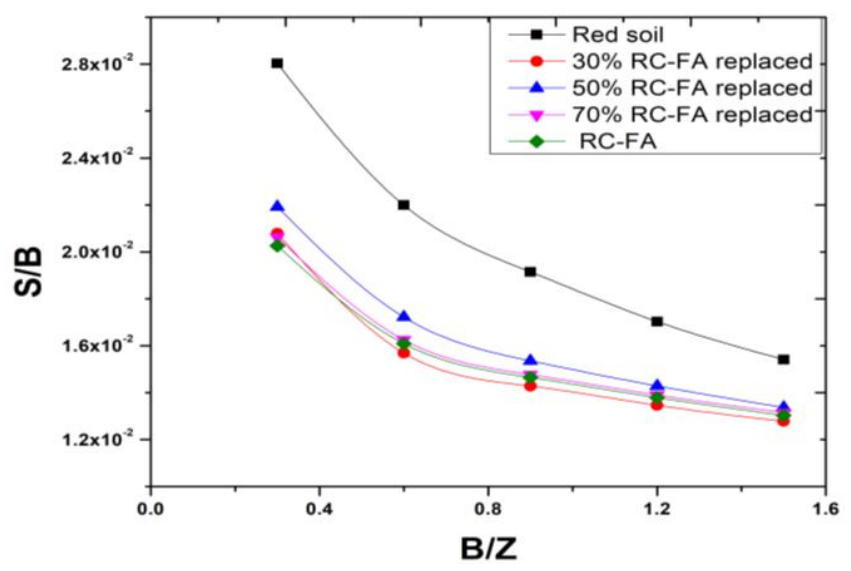

Fig. 10. Settlement ratio versus Normalized width

\section{CONCLUSION}

Recycled concrete fine aggregate RC-FA is assessed for its potentiality as foundation material. Testing has been done on various percentages of RC-FA blended with soil. Properties obtained from the tests were used to model a footing in Sigma $\backslash W$. The following conclusions were drawn:
- Optimum Moisture Content and Maximum Dry density plays a prominent role in compaction. It was observed that at 30\% replacement of RC-FA and red soil gives highest MMD and lowest values of OMC.

o The shear strength of RC-FA blended soils was meeting the requirements of foundation material and found to be highest at $30 \%$ RC-FA substitution ( $c=10.45 \mathrm{kPa}$; $\phi=$ $40.26^{0}$ )

o From Sigma modelling, it was observed that $30 \%$ supplanting of RC-FA with soil gives most minimal settlements when top $1 \mathrm{~m}$ of soil was replaced below foundation with various proportions. Hence, the enhanced bearing capacity of the soil can be utilized.

o It is recommended that for soil with well graded sand, $30 \%$ of RC-FA replacement gives better performance as foundation material.

\section{REFERENCES}

1. Asokan Pappu, A., Mohini. Saxena and Shyam R.Asolekar (2007). "Solid Wastes Generation in India and their Recycling Potential in Building Materials.” Building and Environment 42: 2311-2320

2. A. Arulrajah, J. Piratheepan, M.W. Bo, and N. Sivakugan (2012) Geotechnical properties of recycled crushed brick blends for pavement sub-base applications. Canadian Geotechnical Journal, 2012. 49(7): p. 796-811.

3. Arulrajah, A., Piratheepan Jegatheesan, Ali MMY and Myint Win Bo (2012) Geotechnical properties of recycled concrete aggregate in pavement subbase applications. Geotechnical Testing Journal, 2012. 35(5): p. 1-9

4. A.Arulrajah, J.Piratheepan, and M.M.Disfani (2013) Reclaimed asphalt pavement/recycled concrete aggregate blends in pavement subbase applications: laboratory and field evaluation. Journal of Materials in Civil Engineering, 2014. 25(2): p. 1920-1928.

5. Alireza Mohammadinia., Arul Arulrajah., Jay Sanjayan., Mahdi M. Disfani., Myint Win Bo., and Stephen Darmawan. (2015) "Laboratory Evaluation of the Use of Cement-Treated Construction and Demolition Materials in Pavement Base and Subbase Applications" J. Mater. Civ. Eng. ASCE

6. Bennert, TPapp Jr, W JMaher and A Gucunski, N (2000) Utilization of construction and demolition debris under traffic-type loading in base and subbase applications. Journal of Transportation Research Record, 2000. 1714(1350): p. 33-39.

7. Jayatheja M., Anasua GuhaRay, Ashok K. Suluguru, Anurag Anand \& Arkamitra Kar (2018): Performance of cohesionless soil partially replaced with building derived materials as a foundation material under static loading conditions, International Journal of Geotechnical Engineering.

8. Shiva Bhushan J.Y.V., Parhi P.S., Umashankar B. (2019) Geotechnical Characterization of Construction and Demolished(C\&D) Waste. In: Stalin V., Muttharam M. (eds) Geotechnical Characterisation and Geoenvironmental Engineeering. Lecture Notes in Civil Engineering, vol16. Springer, Singapore

\section{AUTHORS PROFILE}

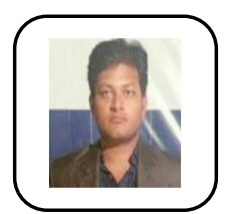

JYV Shiva Bhushan working as Assistant Professor in VNR VJIET and a research scholar in JNTU- HYD. He obtained BTech from JNTU-CEA and MTech from IIT-HYD. He had published papers in National and International conferences.

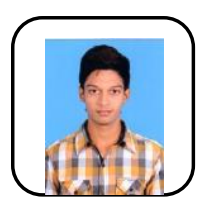

A .Raj Kumar, MTech student at VNR VJIET.

Published By:

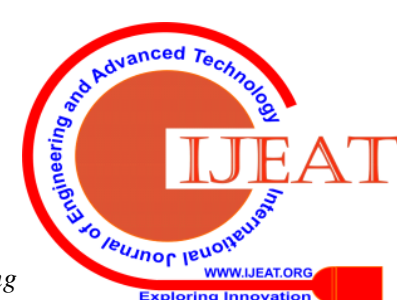

